\begin{tabular}{|c|c|c|c|}
\hline KULTURA & $\begin{array}{l}\text { POLSKA } \\
\text { KOMITET } \\
\text { INSTYTU }\end{array}$ & $\begin{array}{l}\text { AKADEMIA NAUK } \\
\text { SOCJOLOGII } \\
\text { T STUDIÓW POLITYCZNYCH }\end{array}$ & ISSN 0023-5172 \\
\hline & 2016, nr 1 & KULTURAMI: SZKICE I & NOTATKI \\
\hline
\end{tabular}

TOMASZ SAHAJ

Akademia Wychowania Fizycznego im. Eugeniusza Piaseckiego w Poznaniu

\title{
PODRÓŻE I WŁÓCZĘGI ROWEROWE ANDRZEJA BOBKOWSKIEGO
}

\begin{abstract}
„Myślałem, że skoro tworzy się dla zwierząt rezerwaty, parki narodowe, że skoro dba się o to, aby choć na ograniczonych terenach, nie zniknął żubr, niedźwiedź, jeleń, to byłby już najwyższy czas pomyśleć o stworzeniu jakichś rezerwatów dla ludzi wolnych, rezerwatów wolności. Bo człowiek, który naprawdę kocha to najniebezpieczniejsze ze wszystkich stworzeń - wolność - staje się już tak samo rzadki, jak żubr lub jeleń”.
\end{abstract}

Andrzej Bobkowski, Szkice piórkiem

Andrzej Bobkowski (1913-1961) to dziś już nieco zapomniany pisarz i filozof-amator, krytyk totalitarnych systemów społecznych i wolnomyśliciel, a przy tym entuzjasta turystyki rowerowej, miejskiej i plenerowej. Uznanie czytelników i krytyków zyskał głównie dzięki utworom literackim o charakterze pamiętników, swoistym reportażom ze stanu ówczesnego świata: Szkice piórkiem (Bobkowski 1957a-b) i $Z$ dziennika podróży (2006), a także obfitej epistolografii. Jego powieści, pisane w późniejszym okresie na emigracji w Gwatemali, zdobyły umiarkowaną akceptację odbiorców. Kondycja psychofizyczna Bobkowskiego oraz jego konstrukcja jako bytu kulturowego i społecznego zostały ukonstytu-

Adres do korespondencji: sahaj@awf.poznan.pl; Pracownia Filozofii i Socjologii, Wydział Turystyki i Rekreacji, Akademia Wychowania Fizycznego im. E. Piaseckiego, 61-871 Poznań, ul. Królowej Jadwigi 27/39. 
owane na wzór filozoficznego ideału platońskiej kalokagatii. Platon sądził, że „[...] jeżeli ktoś gimnastyką dużo się zajmuje, robi wysiłki i odżywia się bardzo dobrze, a muzyki i filozofii nie tyka [...] czując się dobrze fizycznie, czyż nie nabiera pewności siebie [...] robi się odważniejszy, niż był? [Jeśli] nauki żadnej i żadnych zagadnień nie kosztuje, ani się myślą żadną nie zabawia, ani innym kulturalnym zajęciem, to [...] taki się staje wrogiem intelektu i kultury duchowej; już nie potrafi niczego skutecznie dowodzić w dyskusji, poczyna sobie po barbarzyńsku i chce gwałtem dochodzić wszystkiego jak dzikie zwierzę" (Platon 1991, s. 170).

Bobkowski otrzymał staranne wykształcenie zarówno pod względem duchowym, kulturowym oraz społecznym, jak i fizycznym. Edukowany był jednakowo intensywnie w zakresie kultury cielesnej i sportu, jak i muzyki, literatury, języków obcych (nowożytnych i starożytnych); występował też w teatrze amatorskim. Za wszechstronną aktywność ruchową, z mnogością różnorodnych dyscyplin i konkurencji sportowych, odpowiadał surowy i wymagający ojciec Henryk, wysokiej rangi oficer, profesor wf w szkole wojskowej. To on zaszczepił synowi odpowiednie nawyki i zachowania prozdrowotne, przyczyniając się do jego cielesnego ukonstytuowania i zyskując uznanie syna. Dał on temu wyraz, pisząc w Szkicach piórkiem: ,Jakże wdzięczny jestem ojcu, że choć nieraz brutalnie, ale uformował mi ciało na obraz i podobieństwo ludzkie. Dziś równie dobrze i łatwo pływam, jak myślę. Myślę całym sobą. Nie mogę natomiast znieść i brzydzę się czystych intelektów" (Bobkowski 1957b, s. 292). Z kolei za miękkie kompetencje społeczne i wiedzę o charakterze humanistycznym odpowiadały kobiety z jego najbliższej rodziny: matka Stanisława, ciotka Wanda — doktor filozofii na Uniwersytecie Jagiellońskim — oraz żona Barbara Birtusówna, wierny czytelnik i oddany redaktor tekstów literackich Andrzeja Bobkowskiego.

\section{PASJA ROWEROWA BOBKOWSKIEGO}

O tym, jakie inspiracje filozoficzne zaważyły na myśli Bobkowskiego i jakim intelektualnym wpływom ulegał, edukując się w tym zakresie do końca życia, pisałem obszernie w innych miejscach (Sahaj 2015a; 2015b), więc wątek ten, skądinąd pasjonujący i ważki, nie będzie tu eksploatowany. Podejmując zaś problematykę podróży rowerowych opisanych w sztandarowych utworach Bobkowskiego, skupię się na jego aktywności fizycznej oraz formach ekspresji zawartych $\mathrm{w}$ wybranych utworach: radości $\mathrm{z}$ jazdy wyrażanej expressis verbis, $z$ wykorzystaniem najróżniejszych środków wyrazu. Z całą pewnością można o Bobkowskim powiedzieć, że dotknęła go namiętna pasja, nieuleczalna "choroba”, zwana dziś w środowisku rowerzystów żartobliwie „cyklozą”. Był „cyklomaniakiem”, fanem rowerowym, dozgonnym entuzjastą. Kochał rowery, jazdę nimi, która była dla niego kwintesencją aktywnego życia; życia w ruchu, bycia wolnym. Na rowerze odbył większość swoich wypraw sportowo-turystycznych, a relacje o jeździe na nim i umiłowaniu takiego sposobu spędzania czasu poja- 
wiają się od początku jego autobiograficznych notatek i zapisków, aż do końca życia. Maciej Urbanowski słusznie zauważa: „[...] książki Bobkowskiego spaja motyw podróży, choć ma ona tutaj rozmaite oblicza, bo czym innym jest turystyczna wycieczka po Pirenejach, czym innym pielgrzymka do Lourdes, czym innym wreszcie wyprawa transatlantykiem "Jagiełło" na emigrację do Gwatemali. W każdym jednak przypadku Bobkowski jawi się nam jako nowoczesny homo viator, człowiek w drodze, ktoś, kto jest w nieustannym ruchu, i to ruchu nie tylko i nie tyle fizycznym, ile przede wszystkim w «ruchu» intelektualnym i duchowym. Bobkowski to oczywiście podróżnik niesłychanie cielesny, sensualny, intensywnie chłonący rzeczywistość wzrokiem i węchem i oddający urodę «skóry» świata za pomocą kilku precyzyjnych "pociągnięć» pióra" (Urbanowski 2013, s. 96).

Jazda rowerem od dziecka była dla Bobkowskiego jednym z najbardziej ulubionych rodzajów sportu. W Krakowie w trakcie studiów poruszał się po mieście rowerem z szalonymi, nawet jak na dzisiejsze warunki, prędkościami (Podolska 1998, s. 9-10). Swoją pasją wpisywał się w nurt cyklistów, rosnący w siłę od końca XIX wieku, a w okresie międzywojennym w niepodległej Polsce zaktywizowany, co przejawiało się choćby w zawiązywaniu rowerowych towarzystw, równie modnych i popularnych jak gimnastyczne i wodne Janiszewska 2012). Bolesław Prus 20 marca 1898 r. dokonał wpisu w „Księdze Pamiątkowej” Warszawskiego Towarzystwa Cyklistów: „Bodajbyśmy doczekali w zdrowiu: tak tanich rowerów, ażeby nawet najskromniejszy pracownik mógł zdobyć się na kupno tak szacownej machiny. Tak wygodnych dróg bocznych, ażeby po najgorszej z nich mogli jeździć. Takich stosunków, ażeby zarówno chłop, jak i mały mieszczanin, zobaczywszy na swoim terytorium cyklistę, witał go z daleka" (cyt. za: Łuba-Wróblewska 2010, s. 5). Przed wybuchem pierwszej wojny światowej, podczas dwuletniego pobytu w Krakowie i na Podhalu, intensywnie rowerem jeździł na długie dystanse Włodzimierz Iljicz Lenin (Sahaj 2008). Miłośnikami „bezcelowych” włóczęg rowerowych byli małżonkowie Maria i Piotr Curie, którzy bicykle dostali w prezencie ślubnym. Pasja przetrwała śmierć męża u tej jedynej na świecie kobiety z dwoma Nagrodami Nobla, jaką była Skłodowska-Curie, która ubrania do jazdy z konieczności musiała szyć sobie na miarę u krawca, a wydatki rowerowe uwzględniała w budżecie domowym (Sahaj 2011). Mylił się niemiecki filozof kultury Walter Benjamin, krytykując i niedoszacowując społeczne znaczenie roweru (Benjamin 1975). Podobnie mylił się wybitny rosyjski socjolog Pitirim A. Sorokin (2009, s. 352 i s. 376), twierdząc z przekonaniem, że moda na jazdę rowerem szybko okaże się przemijająca, aczkolwiek genialna okazała się jego intuicja dotycząca ślepej uliczki powszechnej scholaryzacji i nadprodukcji absolwentów wyższych uczelni (Sorokin 2009, s. 190-195) oraz roli i znaczenia „oświeconych” turystów (Sorokin 2009, s. 498-499).

Bobkowski nie był pionierem $\mathrm{w}$ dziedzinie sportu rowerowego ani nie był stowarzyszony; była to po prostu jego pasja. Jako skrajny indywidualista naj- 
częściej podróżował sam, chętnie z żoną, sporadycznie zaś z pojedynczymi przyjaciółmi. Rower był dla niego urządzeniem pozwalającym realizować nieskrępowaną wolność na dużej przestrzeni, w sposób dla niego akceptowalny i sprawiający niewysłowioną radość. Na świat patrzył poprzez pryzmat dostępności jazdy rowerem. W jednym z listów do Jarosława Iwaszkiewicza Bobkowski (2009, s. 89) napisał: „Taksuję miasta według tego, czy bardzo mnie w nich wytrzęsło na rowerze". Na dobrowolnej emigracji we Francji zachwycały go rowery, po Paryżu, w którym mieszkał, latami przemieszczał się głównie za ich pomocą. Przez pewien czas pracował jako mechanik rowerowy; kilka egzemplarzy dla przyjaciół i znajomych składał w mieszkaniu, ku rozpaczy żony. W czasie wojny, gdy dostęp do części był utrudniony, tryumfował zdobywając niezbędne podzespoły zadowalającej jakości. Gdy musiał sprzedać swój wysłużony rower, czuł się jak zdrajca i upił się z rozpaczy po ukochanej maszynie, antropomorfizował ją: „Wsiadłem na ulubionego grata, który w ciągu tych lat, obwiózł mnie po trzech czwartych Francji, dzięki któremu pokochałem ten kraj prawie tak samo, jak mój własny i jechałem dziś na nim po raz ostatni «moimi» ulicami, ażeby go - sprzedać. Tam, gdzieś wewnątrz, skowytałem jak szczenię. Wydawało mi się, że i on piszczy pode mną, choć do ostatka bardzo o niego dbałem. A jednak w chrzęście łańcucha i tykaniu wolnego koła były jakby cichutkie słowa wyrzutów" (Bobkowski 2006, s. 59).

O swój rower toczył bójkę ze złodziejem, rowerem uciekał przed Niemcami z Paryża, w cieniu poboczy przeczekując naloty i bombardowania dróg przez wrogie samoloty. Po kilkutygodniowej górskiej wyprawie rowerem wracał do okupowanej już stolicy Francji. Epicki opis tych niemal Odyseuszowych peregrynacji znajdujemy w Szkicach piórkiem. Po osiedleniu się w Gwatemali Bobkowski (1998a, s. 76) tęsknie wypatrywał rowerów na wystawach sklepowych i pisał o tym pozostałej w Polsce matce (Bobkowski 1998b, passim). Wątki rowerowe przewijają się we wszystkich jego pismach, zwłaszcza autobiograficznych, w szczególności epistolograficznych (np. w listach do Jerzego Giedroycia i Jarosława Iwaszkiewicza). Przede wszystkim zaś na rowerze dokonywał sławetnych podróży, które choćby przez to, że odbywały się podczas niemieckiego najazdu na Francję, mimo i obok toczącej się wojny (mijał zepsuty samochód Goeringa otoczonego żandarmami), i w trakcie okupacji, uczyniły Bobkowskiego kimś niezwykłym i do pewnego stopnia sławnym - przynajmniej w niektórych kręgach, głównie literackich i w środowiskach badaczy podróży i turystyki.

\section{PODRÓŻE, REKREACJA, TURYSTYKA ROWEROWA — PRZYGODA ŻYCIA}

Już jeden z pierwszych wpisów Szkiców piórkiem, pochodzący z 20 sierpnia 1940 r., streszcza „,filozofię życia” jego autora: „Wracałem o zmroku, jadąc wśród winnic. [...] Zsiadłem $z$ roweru i zerwałem ciężką kiść czarnych owoców, pokrytych prześlicznym sinawym puszkiem. Wgryzałem się w nie spragniony 
[...]. Czułem tylko, jak intensywność życia wzmaga się we mnie do ostateczności. Czułem swoją młodość, przeżyłem ją w tych kilku chwilach tak, że krew powinna była mi trysnąć ze wszystkich por i pomieszać się z sokiem $z$ winogron. Złapałem życie na moment, ale wyraźnie. To było wspaniałe" (Bobkowski 1957a, s. 68). Jakże podobne jest to do relacji Alberta Camusa, którego pisma (podobnie jak Jean Paul Sartre'a) Bobkowski znał (i z Nobli obu tych filozofów cieszył się): „W pewnym sensie przeżywam tu swoje życie, życie o smaku gorących kamieni, pełne westchnień morza i cykad [...]. A przecież mówiono mi nieraz, że nie ma powodu do dumy. Ależ tak, jest powód: słońce, morze, moje serce pulsujące młodością, moje ciało o smaku soli i ta olbrzymia sceneria, w której czułość i uniesienie łączą się w żółcieniu i błękicie" (Camus 1981, s. 11).

Przygotowując się do, jak się miało okazać, wyprawy życia, Bobkowski intensywnie trenował na długich dystansach: biegał, jeździł rowerem, pływał. Ponadto gromadził deficytowe zapasy żywności, kompletował ekwipunek (namiot, sakwy), zbierał mapy (w tym z wyścigu Tour de France z 1936 r.), skrupulatnie planował całą podróż. Wraz z przyjacielem 6 września 1940 r. wyruszyli w trasę przewidywaną na ponad 1500 km, dróg głównie górskich, bardzo wymagających, zwłaszcza dla jeźdźców z ciężkim bagażem. Bobkowski protokołuje: „[...] rowery zmieniły się w coś w rodzaju dwugarbnych wielbłądów. $\mathrm{Na}$ tylnym bagażniku miałem pełny plecak, na tym koc owinięty w gumowy płaszcz, na tym duży plecak z jedzeniem, a na tym komplet menażek, przyczepiony do chlebaka, czyli do «spiżarni». Na przednim bagażniku miałem chlebak $z$ całą bielizną i butelkę wina. Cały ten bagaż ważył około 30 kilo. [...]. Ledwo można prowadzić, a jak jechać? [...]. Rowery wyprowadziliśmy za zakręt, bo baliśmy się na nie wsiadać. [...] Zdawało mi się, że cały rower gnie się, że rama wichruje i że lada moment coś trzaśnie. [...] Wytoczyliśmy się na szosę, jak dwa ciężkie czołgi" (Bobkowski 1957a, s. 89).

Mimo wszystko ruszyli. „Rowery idą coraz lepiej i bierzemy już śmiało kilka wzniesień. Przy zjeździe $z$ góry opony śpiewają na asfalcie i cały rower toczy się jak ołowiana kula" (Bobkowski 1957a, s. 90). Sprzymierzeńcem jeźdźców okazało się wrześniowe słońce za dnia i gwiaździste niebo ciepłych nocy. Nocowali w namiocie pod kocami, gotowali na ognisku, odczuwając „nieopisane szczęście”, „radość istnienia”, „zwierzęce zadowolenie”, którego nie psuła świadomość odczuwanego od początku braku przerzutek, niezbędnych $\mathrm{w}$ rowerach podczas górskich wypraw, a na pewno wpływających na komfort jazdy. Nie to było jednak najważniejsze w tej wyprawie jej istotą były ekstatycznie doznania cyklistów, brawurowo opisane przez Bobkowskiego: „Opony cichutko kwilą na asfalcie i na każdym zakręcie kładziemy się miękko na bok. Przy dużej ilości serpentyn jest to po prostu tańcem na rozpędzonej maszynie. Obciążony rower «leży» przy takich szybkościach wspaniale. Do tego Tadzio porozciągał nasze wąskie, wyścigowe kierownice i leżymy na nich wygodnie, rozparci szeroko i pewnie. [...] wylatujemy z lasu, jak 
dwa pociski z lufy i wypadamy na prosty kawałek drogi" (Bobkowski 1957a, s. 106).

Przerwy $w$ jeździe przyjaciele $z$ premedytacją wybierają $\mathrm{w}$ miejscach ze szczególnie pięknym widokiem, dzięki czemu skromne jedzenie smakuje im jeszcze bardziej. Nawet konieczność prowadzenia rowerów pod górę, niekiedy wielogodzinna, sprawiała im radość, bo mieli wtedy możliwość podziwiania wspaniałych górskich plenerów. Bobkowski notował swoje odczucia w każdej wolnej chwili na postojach, by skondensowane wrażenia z jazdy nie zwietrzały, dzięki czemu w relacjach tych czuć autentyczność i intensywność istnienia. Pazur sportowy jeździe dodaje zmienność faktur podłoża, po którym się poruszają: „[...] długi zjazd ostrymi serpentynami; niektóre mają kształt «U», zakręt o 180 stopni, cięciwa tego łuku ma najwyżej 20 metrów. Wiraże są posypane, jak tor wyścigowy i jazda jest wprost pasjonująca" (Bobkowski 1957a, s. 129). Obaj podróżujący są dobrze przygotowani kondycyjnie, aktywnie odpoczywają kąpiąc się i pływając w miejscach znajdujących się w pobliżu ich obozu. Jazda rowerem, górska włóczęga, jest jednak dla nich prymarną, ekscytującą przygodą. I to jaka jazda: „Wściekłe serpentyny, miejscami długie tunele. Jest to już jazda naprawdę wysokogórska. Oślepieni słońcem wpadamy do tuneli zupełnie ciemnych i ślepniemy. Kierunek utrzymuje się tylko dzięki jasnej plamie wyjazdu $z$ tunelu, widocznej na końcu. Droga jest prowadzona, jak trasa trudnego biegu zjazdowego. $Z$ tunelu wypada się na zbocze, leci się kilka stromych serpentyn i wpada się $z$ powrotem $w$ tunel, jak w bramkę. Rozwija się przy tym szybkości zupełnie nie rowerowe - do $60 \mathrm{~km} /$ godz." (Bobkowski 1957a, s. 150).

Bobkowski, wzorem wielu innych podróżników odnoszących się, często intuicyjnie, do dyskursu toczonego przez teoretyków na temat tego, kim jest prawdziwy turysta i czym jest autentyczne podróżnicze poznanie, uważa, że nie wystarczy jeździć po danym kraju pociągiem lub samochodem, sypiając w hotelach i z perspektywy „klienta” rozmawiać z „tubylcami”. Żeby doświadczenie było autentyczne, a poznanie prawdziwe, należy w danym kraju „żyć”, ,posmakować go" (Bobkowski z zapałem wdychał zapach powietrza i ziemi). Podejmujący tę kwestię już w latach siedemdziesiątych-osiemdziesiątych XX wieku Erik Cohen zauważa: „Problem z zastosowaniem pojęcia «autentyczności» w studiach nad turystyką bierze się stąd, że pojęcie filozoficzne w dość bezkrytyczny sposób przeniesiono w obszar analiz socjologicznych. Ponadto w pracach dotyczących turystyki mówi się o nim jako o kategorii wartościującej, używanej przez nowoczesnych turystów-obserwatorów. Rzadko natomiast pojawia się pytanie, czy w oglądanych przez turystę społecznościach koncepcja taka w ogóle istnieje, a jeśli tak, to jakie cechy własnej kultury uważane są za «autentyczne». Co więcej, socjologowie zdają się zakładać, że skoro, podobnie jak turyści, należą do świata nowoczesnego, to rozumieją turystyczne poszukiwanie autentyczności" (Cohen 1988, s. 375; cyt. za: Wieczorkiewicz 2012, s. 33-34). Wypowiedz tę dopełnia Agnieszka Gotchold (2013, s. 7): „Metafora podróży umożliwia podjęcie szerokiej gamy refleksji nad conditio humana. Odzwiercie- 
dla ona dążenie człowieka nie tylko do poznania świata, innych ludzi i kultur, ale także, a może nawet przede wszystkim, do samopoznania. Podróż staje się metaforą ludzkiego życia: dorastania, dojrzewania, poszukiwania prawdy, a także śmierci (ostatnia podróż). Tradycja opisywania wszelkiego rodzaju podróży, mających wymiar sakralny, egzystencjalny bądź przygodowy, jest długa i bogata".

Górskie drogi przetestowały kondycyjne przygotowanie, sprawność i wytrzymałość obu kolarzy, którzy wielokrotnie musieli nie tylko zdobywać wysokie przełęcze górskie, ale następnie zapierając się nogami nie pozwolić, by obładowane jukami rowery dosłownie wyrwały im się z rąk. Od połowy września o poranku i wieczorami jest w górach bardzo chłodno, a nocami wręcz lodowato. Szybką jazdę z góry niekiedy utrudniała wyraźnie odczuwalna niska temperatura i smagający ciało zimny wiatr. Około 19 września 1940 r. Bobkowski notuje: „[...] rower skacze do przodu, jakby miał motor. [...] Po dziesięciu kilometrach tej jazdy ręce mam zupełnie zdrętwiałe. Przymarzły do hamulców. Nóg nie czuję w ogóle; zbite lodowatym wiatrem, zwisają przy siodełku, jak obcy przedmiot. [...] Upijam się prawie do nieprzytomności szybkością, furkotem wiatru przy uszach i tańcem na zakrętach. [...] co by się stało, gdyby widełki pękły? Przy takiej szybkości i obciążeniu drgały one [...] jak uderzony kamerton" (Bobkowski 1957a, s. 154). Na stromych górskich odcinkach opisy szalonych zjazdów rowerowych nabierają zmysłowej intensywności i skoczności, jak przy tańcu kujawiaka, oberka lub polki. Bobkowski relacjonuje: „Puszczam hamulce, skaczę od razu na 40, 50, 55, 60 - strzałka [prędkościomierza — T.S.] utyka i utyka oddech w piersiach. Zakręt, skok mostkiem na drugą stronę rzeki, zapach mokrych bierwion ułożonych przy drodze, żywicznych i sękatych, mroczne wrota krótkiego tunelu. W tunelu asfalt jest wilgotny i opony mlaskają na nim tak, jakby pociągnięty był klejem. Pachnie pleśnią i grzybem" (Bobkowski 1957a, s. 154).

Pod koniec chłodnego, choć na ogół pogodnego września 1940 roku obaj jeźdźcy rowerowi robią dzienne średnie trasy długości $80-100 \mathrm{~km}$, odczuwając już wyraźne zmęczenie. Jest ono zupełnie zrozumiałe, zważywszy na intensywność eskapady, prostotę i skromność diety, specyfikę górskich dróg i ich fakturę, jesienną pogodę, biwakowo-polowe, spartańskie warunki noclegów pod namiotem i zabiegów higienicznych dokonywanych w strumieniach, rzekach oraz jeziorach. Coraz częściej decydują się na bardziej „cywilizowane”, stacjonarne warunki: jeśli tylko nadaży się stosowna okazja, sypiają w opuszczonych szopach i odludnych stodołach, nie gardząc zadaszonymi budami prowizorycznie skleconymi z paru desek. W analogiczny sposób podróżował po całej Europie, chłonąc jej uroki, twórca określenia „filozofia roweru” - poznański filozof Tomasz Węcławski vel Polak (1997). On jednak jeździł na eskapady liczące wiele tysięcy kilometrów latem, gdy było ciepło, sypiał w stogach siana lub kopkach świeżo zżętego zboża. Bobkowski z przyjacielem na przełomie września i października roku 1940 nieraz budzili się oszronieni przez pierwsze przymrozki. 
Po znalezieniu się na równinach rowerzyści nie zdecydowali się na zakończenie podróży pociągiem, na co wskazywałby zdrowy rozsądek oraz dotkliwie odczuwane braki aprowizacyjne. Ci rowerowi włóczędzy, wyglądem coraz bardziej przypominający kloszardów, uznali przerwanie podróży przez takie „drobiazgi" za niesportowe. Przejechawszy 1300 km odcinków górskich, ostatnie $300 \mathrm{~km}$ zdecydowali się pokonać mimo wszystko za pomocą własnych nóg, nadal intensywnie pedałując. Ich decyzji nie zmieniły pierwsze naoczne przejawy okupacji Francji, zetknięcia z surowymi żandarmami, ani gotowość bezinteresownego finansowego wsparcia ze strony schludnego oficera niemieckiego, będącego pod ogromnym wrażeniem ich przedsięwzięcia. Bobkowski płynnie mówił po niemiecku (urodził się w Wiener Neustadt, w ówczesnej Austrii), co ułatwiło mu przejazd do Paryża $\mathrm{w}$ nie mniejszym stopniu jak specjalna ścieżka rowerowa wiodąca do stolicy Francji. „Paryż jest cichy. Ulicami jeżdżą już tylko niemieckie samochody, a poza tym rowery. Rower jest zasadniczym środkiem lokomocji; Paryż zmienił się w Kopenhagę" (Bobkowski 1957a, s. 199) —informuje Bobkowski 3 października 1940 r. A może raczej w Berlin lub Królewiec, bo w stolicy Francji panuje już niemiecki porządek i pruski rygor: „Za brak czerwonego światła przy rowerze kara do 200 franków" (Bobkowski 1957a, s. 202).

\section{MIEJSKIE I PLENEROWE PEREGRYNACJE ROWEROWE}

Po sześciu tygodniach górskiej wyprawy i 1600 km rowerowej łazęgi Bobkowski z eskapad plenerowych przestawia się na jazdę miejską. Rower bowiem jest jego podstawowym środkiem lokomocji, atrybutem $w$ zasadzie $z$ nim nierozerwalnym. Latem $w$ górach ekscytował się zapachem gór i smakiem podróży, jesienią okupacyjną $z$ równie wielkim entuzjazmem jeździ rowerem, penetrując śmietniki w poszukiwaniu resztek jedzenia. I przyznać trzeba, że czyni to heroicznie, z pieśnią na ustach, niczym zwycięskim hymnem bojowym jego witalności. Rok po zakończeniu górskiej rowerowej wyprawy, 4 września $1941 \mathrm{r}$. opisuje: „Pędzę na rowerze na złamanie karku [...]. Położyłem się na kierownicy, gwiżdżę «Torreadora» [...], przechodzę na marsz Schuberta [...], wpadam na Rond-Point z szybkością 60-ciu km na godzinę" (Bobkowski 1957a, s. 254). Jego entuzjazm rośnie do granic możliwości po znalezieniu w śmietniku głowy barana i wywalczeniu jej (przy użyciu roweru jako oręża) w zaciętej walce $z$ wściekłym psem. Tryumfalnie wkracza do mieszkania z rowerem i niezwykłym trofeum pod pachą. Opis uczty, którą wówczas przyrządził, dorównuje zmysłowością kulinarnym podróżom i wycieczkom słownym Roberta Makłowicza. Syty i zadowolony Bobkowski czyta w fotelu prace intelektualistów i filozofów.

Filozof Michał Heller (2014, s. 269) trafnie konstatuje: „[...] dobrze jest, gdy przygody podróży mieszają się przygodami intelektualnymi”. Epikurejskie zadowolenie Bobkowskiego ufundowane zostało na jeździe rowerem. Przyznaje on z charakterystyczną dla niego prostotą sybaryty: „Jest mi tak dobrze. Nieraz 
gdy w zawrotnym tempie uwijam się po ulicach na rowerze, gdy świeci słońce, jestem tak szczęśliwy, jak niemal nigdy w życiu. Odkryłem uśmiech myśli, [...] rozsadza mnie głupia radość i lekkość. Wszystko mi się podoba, wszystko wokół jest jak muzyka. Chwytane w przelocie nastroje poszczególnych ulic i widoki wiją się wewnątrz mnie jak jakiś roztańczony korowód par, każda w innym stroju. Piję coś wielkimi łykami, czego nie umiem określić. Młodość? Dobrze mi, bo jestem młody i silny; dobrze mi, bo jestem sobą i myślę tak swobodnie, jak nigdy dotąd. [...]. Czego więcej trzeba?” (Bobkowski 1957a, s. 254-255). Autentyczne poczucie radości nieskrępowanego niczym psychofizycznego istnienia, pomimo okupacji i toczącej się „gdzieś” wojny, radości opartej na cudem zdobytej, skromnej, lecz smacznej diecie, dobrej lekturze, poczuciu sprawności i zdrowia, składa się na holistyczny obraz Bobkowskiego. W tym szczególnym kontekście Anna Wieczorkiewicz celnie zauważa: „ „Autentyczność» to pojęcie istotne dla świata nowoczesnego. Jego historię można szkicować od różnych okresów historycznych, idei filozoficznych czy zjawisk społecznych; na ogół przyjmuje się jednak, że koncepcja autentyczności wyłaniała się $\mathrm{W}$ miarę zanikania poczucia związku jednostkowego życia $\mathrm{z}$ pewnym całościowym porządkiem. [...] Hierarchie nakładały na ludzi pewne ograniczenia, ale jednocześnie nadawały głębszy sens wydarzeniom indywidualnym i społecznym. To, co dokonywało się w świecie materialnym, odnosiło się również do sfery duchowej, a ponadto wpisywało we wszechobejmujący system znaczeń. W tym układzie człowiek mógł doświadczać totalności świata, żywiąc zarazem przekonanie, że fizyczny i społeczny obszar, w którym toczy się jego egzystencja, to «jego miejsce» i z miejscem tym wiązać swą tożsamość" (Wieczorkiewicz 2012, s. 34).

Bobkowski przez całą niemiecką okupację, a także przez kilka lat po zakończeniu wojny, intensywnie poruszał się rowerem po Paryżu oraz jego bliższych i dalszych okolicach. Na początku maja 1942 roku nakłonił do jazdy żonę, dzięki czemu ich wspólne życie nabrało nowej jakości: „Kilka dni temu udało mi się kupić okazyjnie damski rower. Dziś rano poszliśmy do lasku Vincennes na pierwszą lekcję. [...] Po kwadransie podtrzymywania Basia zaczęła już jeździć sama, po godzinie nauczyła się zsiadać i wsiadać. [...]. Zjedliśmy przytuleni do siebie [...], a potem jeździliśmy już razem po alejach i ścieżkach. I byliśmy bardzo szczęśliwi" (Bobkowski 1957b, s. 94). Odtąd żona towarzyszyła mężowi w części jego rowerowych peregrynacji; z czasem ich wspólne wyjazdy nabierały intensywności, a pokonywane odległości rosły wraz ze zwiększającą się kondycją obydwojga. Korzystając $z$ uroków wiosny często wyjeżdżali na rowerach już z samego rana, zdarzało się im jednak wyruszać do miasta $\mathrm{w}$ poszukiwaniu przygód i „powłóczenia” się po nim wieczorem, przed definitywnym zapadnięciem nocy. Zaskakuje zarówno to, że równo tydzień po pierwszej lekcji nauki jazdy jego żona jest gotowa i skłonna do pokonywania kilkudziesięciokilometrowych tras rowerowych, jak i to, że podczas tych podróży nie byli bynajmniej jedynymi cyklistami, pomimo dokuczliwości niemieckiej okupacji. Bobkowski 
pisze: „Rano pojechaliśmy nad Marnę. Dzień ciepły i słoneczny [...], ruch jak na promenadzie w Cannes. Wszystkie wypożyczalnie łódek, kajaków, żaglówek i kanoe otwarte [...], tłum cyklistów jadących w obydwie strony. Potem wracaliśmy po tych małych miasteczkach podparyskich, tak bardzo prowincjonalnych, jakby leżały o setki kilometrów od Paryża. Coś jest tu takiego, że się odpoczywa jak nigdy i nigdzie" (Bobkowski 1957b, s. 96).

Po nadejściu upalnego lata 1942 roku autor Szkiców piórkiem z radością i satysfakcją odnotowuje interesujący fakt nastania najnowszego „krzyku mody”: nagłego wzrostu popularności wśród Francuzów jazdy rowerem. Przed wojną podupadający francuski przemysł rowerowy w trakcie okupacji zdaje się „zmartwychwstawać" i nieustannie rozwijać. I choć ceny rowerów, nowych i używanych, są bardzo wysokie, wielu paryżan decyduje się na ich zakup, płacąc nie tylko pieniędzmi, ale i deficytowymi towarami: jajkami, kawą, tytoniem. Bobkowscy od maja do grudnia 1942 roku korzystają z każdej nadarzającej się okazji, by wyruszyć w plener, wycieczki rowerowe uatrakcyjniając piknikami. W notatce z niedzieli 28 czerwca czytamy: „Dzień śliczny, ciepły, już letni. [...] rozłożyliśmy mapę okolic Paryża i wybraliśmy trasę na dzisiejszy spacer rowerami [...] i pojechaliśmy. Na rowerze plecak z kocem i z książkami, w torbach chleb, masło, kawałek kiełbasy [...] i flaszka wina" (Bobkowski 1957b, s. 108). Niekiedy w tych wyprawach towarzyszą im znajomi. Nieliczne myśli o wojnie, postępach niemieckich dywizji na różnych frontach, skutecznie wypierane są przez impresje rowerowe.

\section{POWOJENNE ROWEROWE WŁÓCZĘGI}

Począwszy od roku 1943 do 1944, na którym Szkice piórkiem się kończą, brak jest adnotacji dotyczących roweru i rowerowych wycieczek. Powrót do tego tematu następuje wraz z pojawieniem się kolejnego dużego autobiograficznego utworu Bobkowskiego: $Z$ dziennika podróży, i to już na samym jego początku, $\mathrm{w}$ drugim rozdziale. Tekst ten powstał na bazie artykułów drukowanych w kolejnych odcinkach w „Nowinach Literackich” tuż po zakończeniu drugiej wojny światowej. Pierwszy odcinek, dotyczący włóczęgi namiotowo-rowerowej, został opublikowany w 1947 roku w numerze 30. Zapiski te mają nie tylko walor osobistych wspomnień autora, ale i opisują realia odnawiającej się europejskiej turystyki tużpowojennej, pookupacyjnej, a tym samym mają charakter fabularyzowanego dokumentu tamtej epoki. Znajdujemy w nim opisy biwakowania i eskapad rowerowych po kilku krajach. W Baskijskim liście czytamy: „Wyjeżdżaliśmy z żoną na rowerach o świcie. Namiot "zamknięty» (zapięty), garnki koło ogniska, jakieś drobiazgi pod okapem. Wiedziałem, że gdy wrócimy, już pewnie w nocy, zastanę wszystko na miejscu i wewnątrz, i zewnątrz. Nawet aparat fotograficzny [...]. Kocham go [ten kraj, tj. Francje - T.S.] za ten opuszczony namiot, z którego nic nie zginęło, choć naokoło wiedziano, że wyjeżdżałem na cały dzień. Szanuję rodziców i ich dzieci, które tam, z wysokich skał ponad 
nami, nie ciskały kamieniami w napięte płótno; cenię kulturę tych, co przyjechawszy podchodzili do mnie i pytali, czy jeśli rozbiją swój namiot o dwadzieścia metrów dalej, mnie to nie będzie przeszkadzać" (Bobkowski 2006, s. 25).

Autor tych słów ulega magii chwili, nie traci jednak zdolności krytycznego myślenia i ewokując najbliższą przyszłość, zdaje sobie sprawę z tego, że taka idylla nie będzie trwała wiecznie. Nie ma przy tym wątpliwości co do stanu moralnego najbliższych pokoleń, wychowywanych $\mathrm{w}$ takim czy innym systemie; zapewne totalitarnym. Stosunkowo rzadki pesymizm, w tym momencie upodabniający go do Stanisława Ignacego Witkiewicza i Ortegi y Gasseta, przebija się w następujących zdaniach: „Któregoś dnia, w jakiejś przyszłości, gdy wrócę do namiotu, mogę go już nie znaleźć. $Z$ początku, być może, aparatu fotograficznego; potem dopiero namiotu, a w końcu może i okopconych garnków. To postępuje szybko. [...] Gdy ta cienka niteczka samej moralności niewzmocniona dobrobytem przerwie się raz, nawrót do "zamkniętych" namiotów będzie bardzo trudny. [...] prawdziwa kultura to nie dziesiątki i setki tych pism, świetnych artykułów i rzutów myśli odwiecznie francuskiej, lecz przede wszystkim ten mój namiot samotny, opuszczony o świcie z zaufaniem. Tamto może przetrwać długo, może przetrwać nawet jeszcze wspanialszym płomieniem. Natomiast ja będę się bat odejść o świcie..." (Bobkowski 2006, s. 26).

Dalsze opisy Bobkowskiego, który biwakował nad wodą w pobliżu granicy z Hiszpanią i był świadkiem „turystyki przemytniczej”, rozwijającej się za sprawą różnicy w kursach walut i zapotrzebowania na deficytowe produkty różne po obu stronach granicy, są protokołem odnawiania się, odradzania powojennej turystyki. W opisach z lipca 1947 roku obok i wokół dotychczas samotnego namiotu Bobkowskich zaczynają pojawiać się inne; przybywa ich, $z$ każdym dniem jest ich coraz więcej. $Z$ jego relacji możemy odczytać socjologiczny przekrój społeczny tych, których na wczasy mogą sobie pozwolić jaki jest ich status i stan majątkowy. „Tu, koło mnie, wyrastały ceglaste i żółte namiociki, jak muchomory i kurki. Tam dalej pozajeżdżały ciężarowe samochody drobnych rzemieślników, kupców i fabrykantów, urządzone jak pokoje. $\mathrm{Ha}$ - zajechał i chłop, ponury i milczący [...] z całym gospodarstwem. [...] Zjeżdżały i «Buicki», i rozłożyste «Pontiaki». Stawał przy nich wielki namiot z łóżkami polowymi i kuchenką gazową. My, rasowe włóczęgi, patrzyliśmy na nich ze zgorszeniem i pogardą" (Bobkowski 2006, s. 27-28). Sam fakt posiadania amerykańskich marek samochodów, a nie rodzimych, francuskich, świadczy o zaradności ich właścicieli, którzy mieli szczęście znaleźć się $\mathrm{w}$ amerykańskiej strefie wpływów. Dla takich „rasowych włóczęgów”, jakimi po pięciu latach wspólnych wyjazdów rowerowych stali się Bobkowscy, gotujących potrawy na ognisku, posiadanie luksusowych akcesoriów biwakowych, pochodzących najpewniej z demobilu, takich jak kuchenka gazowa i łóżka polowe, było dyskwalifikującą oznaką filisterstwa i wygodnictwa.

Bobkowskiego ciągnie $\mathrm{w}$ drogę, $\mathrm{w}$ plener, $\mathrm{w}$ świat; jest rasowym włóczęgą i często tak siebie właśnie określa. W Szkicach piórkiem pod datą 7 sierpnia 
1943 r. czytamy: „Wielka włóczęga po cichych drogach, po cichych miasteczkach. Bez zegarka, bez czasu" (Bobkowski 1957b, s. 292). W jednym z listów do Jerzego Giedroycia pisał: „[...] uważam się po prostu za włóczęgę” (cyt. za: Kowalczyk 2010, s. 20). W rozdziale trzecim $Z$ dziennika podróży, zatytułowanym „Na drogach Francji” i opublikowanym w 1947 roku w 37 numerze „Nowin Literackich”, czytamy opis jego heroicznej, rekonstrukcyjnej trasy rowerowej z 1940 roku, podczas załamania pogody: "Już na «Drodze Napoleona» pogoda zepsuła się zupełnie. Z nagich zboczy Alp Morskich ściekały do wezbranego Varu strumyki z rozpuszczonym łupkiem i zabarwiły go prawie na czarno. Herbata $z$ tej wody ma oliwkowy kolor brazylijskiej herva-mate, a na dnie kubków zostaje szlam. Deszcz pada bez przerwy od trzech dni. Suszę się teraz na fermie. Z $2300 \mathrm{~m}$ przełęczy Cayolle zjeżdżałem w skarpetkach na rękach zamiast rękawiczek. Palce sztywniały z zimna na hamulcach. Asfalt miejscami spłukany zupełnie, droga nienaprawiana od czasu, gdy jechałem tędy w 1940 roku. W kilku miejscach reperowali ją jeńcy niemieccy, doskonale pracując" (Bobkowski 1957b, s. 43). Z kolei Francuzi w małych miasteczkach, do których musi zajeżdżać, by uzupełnić szczupłe zapasy jedzenia lub kupić pęknięte szprychy, co zdarza się często na górskich drogach, wydają mu się egoistyczni, leniwi i nieżyczliwi. Bobkowski, sam głodny w oczekiwaniu na mechanika, który świadom jego oczekiwania zrobił sobie nadmiernie długą popołudniową przerwę, ką́sliwie zauważa: „Francja jest kartezjańska: jem więc jestem" (Bobkowski 2006, s. 43).

Poprawa warunków atmosferycznych, widoki pobliskich szklistych lodowców, a przede wszystkim możliwość jazdy naprawionym rowerem, wprawiły tego krytyka ludzi i systemów społecznych w bardziej optymistyczny nastrój. Trasa nie trwała jednak długo — skończyły się niewielkie zasoby pieniędzy, żywność sprzedawana we Francji po wojnie na kartki nie była w stanie zaspokoić nawet skromnych potrzeb Bobkowskiego, intensywnie przecież trenującego. Ów zapalony rowerzysta $z$ żalem i tęsknotą żegnał się z miłymi plenerami, zapowiadając im rychły powrót. Poetyckie nastroje, ckliwe i refleksyjne opisy przypominające listy do kochanki, znajdujemy w jego kwiecistych i żarliwych słowach: „Przejeżdżałem przez place, wślizgiwałem się w ulice uciekając przed samochodami, a w oczach miałem winne krzaki przydrożne, osypane sierpniowym pyłem, chłodną zieleń Pirenejów i Alp, szafir i szmaragd obydwu mórz. Nazwy miast i miasteczek, jedynych, o uroku niewyrażalnym, wracały uparcie, żegnały się jakby ze mną, mówiąc: «Czy pamiętasz?». Pamiętam i nigdy nie zapomnę. Nie, stary i ślepy rozpoznam was po zapachu. Nie bójcie się. W moich wszystkich włóczęgach nie «tam» było najładniejsze, lecz zawsze "z powrotem». A czym mniej cenią was w prospektach, tym ja kocham was bardziej. Bądź spokojne, malutkie Gruissan, kopciuszku Narbonne, z bezkresnym stepem twoich plaż, gorącym "Circiusem» i symfonią komarową graną w każdy zmrok. Już raz do ciebie wróciłem. Nie rozpaczaj, skromne Angle, zatrzaskiwane zawsze przez Biarritz. Wrócę, przytulę znowu głowę do czerwonych szpilek twoich 
lasów, rozgrzanych i dusznych, do piasku białego jak pszenna łąka. Rozpoznam was wszystkie" (Bobkowski 2006, s. 59-60).

Żegnając się miłośnie z górskimi plenerami i drogami, składając obietnice powrotu, Bobkowski przeczuwał, że żegna się z Francją, z której niebawem miał na zawsze wyemigrować do Gwatemali. Nostalgię, tęsknotę i żal przelał na papier: „Wrócę do tych tysięcy przyjaciół - słupków kilometrowych w czerwonych kapturkach, mających zawsze do opowiedzenia bajkę ludziom kochającym drogę. I je też pokochałem. Szerokie, proste, lśniące jakby lustra $z$ asfaltu, w których przyglądałem się całymi dniami. [...]. A po nich tom poezji drożynek komunalnych, zakurzonych, zasłuchanych w muzykę pól i częstujących wszędzie to winogronami, to figą lub skromnie - jeżynami. To są zawsze szczodre, od nich czułem Francję najsilniej. Omotały mnie, splątały się w węzły nie do przecięcia" (Bobkowski 2006, s. 60). Wkrótce potem, czując się jak Judasz zdradzający swego wiernego druha, sprzedał rower za 7,5 tys. „Srebrników” i upił się za nie z żalu.

\section{LITERACKIE I ROWEROWE INSPIRACJE}

Fascynujące literacko, sportowo i turystycznie opisy rowerowych wypraw Andrzeja Bobkowskiego, mające $z$ jednej strony cechy i charakter esejów, $z$ drugiej zaś przenikliwych reportaży, czy też po prostu autobiograficznych dzienników podróży, stanowią formę wyrazu bogatej egzystencji. Są do bólu rozkoszy prawdziwe, tak jak równie intymne relacje $z$ włóczęg nadwrażliwego poety i prozaika - Edwarda Stachury. Ich wielorakie podobieństwo przejawia się między innymi przez to, że podróż uruchamiała w obu ukryty mechanizm skryby, działającego pod wpływem ruchu, uaktywniającego bystry strumień myśli. Trafnie uchwycił to jeden z interpretatorów: „Smak życia pisarz odczuwa zwłaszcza w działaniu, w aktywności, a także w «dzianiu się» świata. Gdy rzeczywistość «rusza», to znaczy wyskakuje z kolein codzienności i rytuałów schematyzmu - wtedy uruchamia się u Bobkowskiego potrzeba pisania, będąca funkcją ekscytacji uczestnictwa w "zdarzeniowości». Z takiej materii utkane [...] teksty niefabularne (wspomnieniowe, konfesyjne, eseistyczne itp.)" (Klejnocki 2011, s. 132).

Aktywność, działanie, ruch w czasie i w przestrzeni mają walor dopingu psychofizycznego - zjawisko znane i opisywane zarówno w naukach o kulturze fizycznej, jak i w literaturze filozoficznej oraz podróżniczej. Nie bez powodu podróżujący pociągami czy statkami, pobudzeni intelektualnie impresjami i obrazami świata filozofowie i pisarze, obficie notują swoje refleksje. Dzięki temu mamy dzienniki podróżne między innymi Karela Čapka, Alberta Camusa i Witolda Gombrowicza, współczesnych filozofów: Joanny Bator, Krzysztofa Środy, Marka Bieńczyka, Marka Kamińskiego, a także pisarzy: Andrzeja Stasiuka, Krzysztofa Vargi lub Ziemowita Szczerka. W jeszcze większym stopniu zjawisko to dochodzi do głosu w dziennikach rowerowych, pisanych 
niemal w ruchu, przez takich autorów jak David Byrne i Piotr Durak, wspominany już Tomasz Węcławski vel Polak oraz - najmocniej - u omawianego Andrzeja Bobkowskiego. Nie ma jednak relacji ze swobodnych włóczęg rowerowych przedsiębranych podczas drugiej wojny światowej, lub jest ich niewiele i doprawdy trzeba niemałego trudu, by z przepastnej literatury opisującej bezkresną rzeczywistość czasoprzestrzenną je wyłuskać.

Jednym z nielicznych wyjątków są swobodne łazęgi po błoniach i łęgach w austriackim Altenbergu laureata Nagrody Nobla w dziedzinie fizjologii i medycyny, doktora honoris causa filozofii uniwersytetu w Leeds - Konrada Lorenza - który odrabiając dwuletnią służbę wojskową jako lekarz w Poznaniu lubił jeździć rowerem malowniczą drogą nad jeziora do odległego o kilkanaście kilometrów Strzeszynka. W wyprawach rowerowych w te miejsca często towarzyszyły Lorenzowi ukochane zwierzęta, niczym „bracia mniejsi” św. Franciszkowi: ptaki lub psy. Przyznawał, że zdecydowanie bardziej od prac badawczych wolał wtedy długie wyprawy piesze i rowerowe. Jako Austriak podczas niemieckiej okupacji Polski ulegał jednak wpływowi pruskiego filozofa i rygorysty moralnego: „[...] pracuję właściwie tylko pod presją najcięższego imperatywu kategorycznego Kanta" (Lorenz 2014, s. 119; zob. Michalak 2010).

W tym samym czasie Bobkowski jeździł rowerem po okupowanej Francji i - podobnie jak Lorenz, niepomny na wojnę - zachwycał się urokami przyrody i świata. Relacje te zachowały się dzięki listom do Jarosława Iwaszkiewicza, z którym był, sądząc $z$ tonu i treści listów, w znacznej zażyłości. $\mathrm{W}$ ich korespondencji odnajdujemy te same powojenne przygody rowerowe, co w $Z$ dziennika podróży, ale bardziej intymne, prywatne. Na pocztówce z 18 sierpnia 1947 r. jest zdanie dotyczące wyprawy wzdłuż Wybrzeża Baskijskiego: „Jadę na rowerze - cóż za droga!! Cudo!” (Bobkowski 2009, s. 43). W listach kursujących między zaprzyjaźnionymi pisarzami pojawia się często sformułowanie „włóczęga”. Bobkowski dywagował, czy jego drukowane relacje rowerowe nie zatytułować „notatki włóczęgi” lub „na francuskich drogach”. W liście z 18 września 1947 r. zwierzał się Iwaszkiewiczowi, że czuje się jak kot żony, Burek, który wymyka się cichcem z domu, przez kilka dni go nie ma, wraca głodny, obszarpany i wychudzony, ale przeszczęśliwy i w znakomitym humorze. Bobkowski w ten sposób wyskakiwał w Alpy, które pokonywał w nie gorszym stylu niż zawodnicy Tour de France, co świadczy o jego świetnej kondycji mimo wojennych niedostatków. Chwali się Iwaszkiewiczowi: „Przełęcz Lautaret (ponad $2.000 \mathrm{~m}$ ) wyciągnąłem bez zsiadania $\mathrm{z}$ roweru, przełęcz Cayolle (2.3000) $\mathrm{w}^{1 / 4}$ - nachylenie potworne. Potem w espadrillach (sic) łaziłem po lodowcach Meije, spałem w okolicach $3.000 \mathrm{~m}$ owinięty gazetami i szczękając zębami (bez rękawiczek - wkładałem na ręce wełniane skarpetki), najeździłem się po krótkich trawach, jak na nartach (w espadrillach niosło - ho, ho!) — jednym słowem było do syta i bez grzechu. Strasznie to lubię. Oczywiście sporo notowałem. Z tym listem przesyłam pierwszą część" (Bobkowski 2009, s. $45-46)$. 
W listach tych podkreślana jest przez ich autora potrzeba autentyczności istnienia, pragnienie wolności $\mathrm{w}$ ramach $\mathrm{z}$ konieczności wyznaczonych przez historię i systemy społeczne, po wojnie nakładające się na siebie. Delikatną nitką przewijają się myśli o filozofii, nieobcej przecież Bobkowskiemu, temu czułemu i wrażliwemu barbarzyńcy, który potrafił rowerem wieźć bukiet róż, by podarować je ukochanej żonie, układając zdania, jakimi chciałby opisać drogę do niej prowadzącą. Oto wyimek tej spontanicznej i wzruszającej twórczości miłosno-sportowej: „Droga do Chantilly i Clermont przecina śliczne lasy liściaste, teraz nagie, ale rozsnute na tle wodnistego błękitu jak czarna koronka. Często złaziłem $z$ roweru i szedłem na piechotę. Pachniało ziemią i wilgotną korą, asfalt był mokry i cały odbijałem się w nim, jakbym jechał po taśmie lustra. Za Chantilly wszedłem do lasu, usiadłem na dywaniku ze słońca, zapaliłem fajkę i - czegoś łzy same kapały mi z oczu. Jakiś malutki ptaszek huśtał mi się o pół metra przed nosem na cieniutkiej gałązce i zupełnie się nie bał. I tak sobie to jechałem, to szedłem" (Bobkowski 2009, s. 61).

\section{MIEJSCE BOBKOWSKIEGO W KULTURZE I LITERATURZE}

Szkice piórkiem, Z dziennika podróży oraz obfita korespondencja Bobkowskiego należą do kanonu literatury polskiej. Jego relacje podróżne stanowią obszar starannie pielęgnowanej indywidualnej wolności ich autora. Nadzwyczaj czuły na tym punkcie Andrzej Stasiuk (już choćby przez to, że przebywał w więzieniu, czy dlatego, że podczas jednej $z$ wielu swych podróży widział rosyjskie czołgi wjeżdżające na Ukrainę w 2014 roku) zauważa: „Andrzej Bobkowski przepływa ocean i śni dziewiętnastowieczny sen białego człowieka o wolności, o nieograniczonych możliwościach, o świecie, w którym cywilizacja nie cierpi na starczy uwiąd i jest narzędziem, a nie ograniczeniem. [...]. Wszyscy ci wędrowcy porzucali Europę pewni, że opuszczają tonący okręt. A inne odległe kultury nie jawiły się im jako kuriozum, ewolucyjny błąd czy rezerwat, ale jako konieczna możliwość, równorzędna propozycja albo wręcz weryfikacja ich własnego dziedzictwa. W istocie były wyspami, na których rozbitkowie Zachodu mogli znaleźć ocalenie" (Stasiuk 2000, s. 25; zob. Dębicki 2012).

Włóczenie się rowerem po Europie w czasie, gdy płonie ona podpalona $z$ kilku stron jednocześnie, ekscytacje sportowe, rozkosze jedzenia i podróżowania $\mathrm{z}$ wojną $\mathrm{w}$ tle, mogą zdumiewać i wydawać się osobliwe $\mathrm{z}$ punktu widzenia polskiej martyrologii czy podręcznikowego sposobu prezentacji naszej historii; pewnego habitusu i paradygmatu opisywania rzeczywistości. Ale można także na nie spojrzeć jak na emanację wolności człowieka, który z całych sił pragnie wywikłać się z historycznych konotacji, przez co bywa, zgodnie $z$ jego intencjami, nazywany „kosmo-Polakiem”. Witold Gombrowicz, podobnie jak Bobkowski emigrant do Ameryki Południowej (o mało nie popłynęli tym samym statkiem), uwielbiający czytać dzienniki innych pisarzy, napisał, że autor Szkiców piórkiem odpychając od siebie Polskę „[...] rani sobie ręce do 
krwi”, ale i tak „pępowina nie zostanie przecięta” (Gombrowicz 1971, s. 102), z czym Bobkowski w pełni się zgadzał. Taka interpretacja jego postawy życiowej (zachowania residuum wolności jako wartości nadrzędnej) bliska jest plejadzie interpretatorów i komentatorów filozofii życiowej Bobkowskiego i sprzęgniętej z nią twórczości. W jednej z prac czytamy: „W tym kontekście wolność i upojenie życiem wpisane $\mathrm{w}$ analizowane dzieło nabierają specyficznego zabarwienia. Autobiograf, zanurzony w "wiecznym teraz», uwalnia się od czasu przez kontemplację tego wymiaru, ale co rusz jego literacką relację z wypraw w dziedziny ducha zagłusza pamiętnikarz, którego domeną jest czas linearny. I nic w tym dziwnego, prezentacja dziejów domaga się solidnego oglądu przeszłości i teraźniejszości oraz projektu przyszłości, wykreślonego dzięki analizie tego, co było i jest" (Plucińska-Smorawska 2005, s. 163).

Inna wnikliwa autorka wzbogaca tę wypowiedź o rozbudowaną analizę komparatystyczną: „Relacje $z$ wojennej tułaczki pokazują też jednak niejednokrotnie, że oddziaływanie wieloznacznego symbolu wędrówki ujawnia się szczególnie w momentach trudnych, przełomowych, kiedy nie tylko działanie, ale nawet sama myśl o wędrówce, podróże w wyobraźni stają się formą ucieczki czy zapomnienia, albo też buntu i manifestu wolności, poszukiwania czegoś ponad czas i miejsce, którego doświadczamy. Pisany przez Gustawa Herlinga-Grudzińskiego podczas walk o Monte Cassino esej o sztuce podróżowania nie jest jedynym, choć bardzo znamiennym świadectwem takiego pojmowania wymiaru podróży. Siedzący «na stanowiskach ogniowych artylerii» żołnierz-pisarz zapisał $\mathrm{w}$ tych pozornie nieprzystających do rzeczywistości rozważaniach taką konkluzję: «sztuka podróżowania jest tak jak poezja, malarstwo lub muzyka radosną próbą zawarcia nigdy nie wyczerpanej przyjaźni ze światem». Świadectwem takiej "przyjaźni» są - wyjątkowe na tle wędrówek opisywanych w czasie wojny - Szkice piórkiem Andrzeja Bobkowskiego, pisane przez młodego intelektualistę, który wobec klęski Europy próbuje na własny użytek przeformułować szlacheckie stereotypy Polaka i Europejczyka. Dziennik podróży Bobkowskiego, pisany w 1940 roku, zaskakuje zawartą w nim radością życia płynącą ze zmysłowego "wchłaniania" pokonywanej na rowerze przestrzeni, z zachwytów nad krajobrazem i własną fizyczną aktywnością" (Kozicka 2003, s. 53).

Próbując uplasować osobę i twórczość Andrzeja Bobkowskiego na tle czasów, w których przyszło mu żyć (w pracy tej uwzględniono jedynie jego europejskie peregrynacje), można dokonać wielorakich porównań. Autonomią myślenia pokrewny był takim polskim wolnomyślicielom, jak Henryk Elzenberg, Jan Szewczyk i Tadeusz Kotarbiński, którzy nie pozwolili, aby spętano ich umysły. Cenił Władysława Tatarkiewicza i podziwiał Józefa Marię Bocheńskiego, z którymi osobiście się spotykał. Czytywał Hegla, Camusa i Sartre’a, ale nie pociągnęli go intelektualnie i nie dał im się uwieść. Sposobem narracji najpełniej przejawiającym się poprzez „dzienniki”, „relacje podróżne”, „zapiski” i „listy” Bobkowski przypominał Čapka, Gombrowicza i Stachurę. Jeśli zaś 
chodzi o rowerowe włóczęgi i ich oryginalny — poetycki i zmysłowy, a zarazem skondensowany i kompleksowy sposób prezentacji - to nie ma on sobie równych. Andrzej S. Kowalczyk (2010, s. 28) w sposób syntetyczny mówi o tej symbiozie: „Rowerowa podróż Wybrzeżem Lazurowym stanowi najlepszą literacko część Szkiców piórkiem. Klęskowej wojnie, wydarzeniom decydującym o hegemonii hitlerowskich Niemiec w Europie, przeciwstawiony zostaje turystyczny objazd francuskiej Riwiery, sześć tygodni wakacji; wilegiatura wykradziona historii, wojnie, mobilizacji totalnej, które najpierw zmieniły Europę w obóz warowny, potem $\mathrm{w}$ cmentarz i kupę gruzów. [...] Cała ta wyprawa przez Lazurowe Wybrzeże jest jakimś manifestem sensualistycznym, obfitującym w opisy kąpieli, kontemplacji przyrody, rozkoszowania się światłem i ciepłem, własną sprawnością, zbawiennym pokrewieństwem ciała i natury".

Różnorodne relacje i opis wzajemnie przenikających się związków zachodzących pomiędzy jazdą rowerem, literaturą, filozofią, podróżowaniem i turystyką są oryginalnym wkładem Andrzeja Bobkowskiego w kulturę polską i europejską. Daje to asumpt do zaliczenia go w poczet turystów kulturowych, a nawet sportowo-kulturowych (zob. Sahaj 2015b). Można porównywać podróże Bobkowskiego do wyprawy rowerowej Kazimierza Nowaka po Afryce, ale więcej jest między tymi rowerzystami i stylami ich podróży różnic niż podobieństw; nie sposób sprowadzić ich do wspólnego mianownika. Oryginalność Bobkowskiego polega nie tylko na tym, że z zapałem jeździł na rowerze i pięknie te jazdy opisywał, relacje wzbogacając o raporty o kondycji ówczesnej wojennej Europy. Liczba i jakość tych relacji, bezpośrednio poświęconych podróżom i włóczęgom rowerowym, czyni go pionierem i „ojcem chrzestnym” zjawiska bikepackingu (odróżnianego od backpackingu; zob. Wiza 2013), które w pełnym wymiarze doczekało się naśladowców znacznie później — na przełomie XX/XXI wieku. W tym między innymi tkwi kulturowa moc i siła sprawcza twórczości literackiej Andrzeja Bobkowskiego.

\section{BIBLIOGRAFIA}

Benjamin Walter, 1975, Twórca jako wytwórca, tłum. Hubert Orłowski, Janusz Sikorski, Wydawnictwo Poznańskie, Poznań.

Bobkowski Andrzej, 1957a, Szkice piórkiem. Francja 1940-1944, t. 1, Instytut Literacki, Paryż. Bobkowski Andrzej, 1957b, Szkice piórkiem. Francja 1940-1944, t. 2, Instytut Literacki, Paryż. Bobkowski Andrzej, 1998a, Coco de Oro. Szkice i opowiadania, Wydawnictwo UMCS, Lublin.

Bobkowski Andrzej, 1998b, Listy z Gwatemali do matki, Wydawnictwo Książkowe Twój Styl, Warszawa.

Bobkowski Andrzej, 2006, Z dziennika podróży, Towarzystwo Więź, Warszawa.

Bobkowski Andrzej, 2009, „Tobie zapisuje Europe”. Listy do Jarosława Iwaszkiewicza 1947-1958, Towarzystwo Więź, Warszawa. 
Camus Albert, 1981, Zaślubiny w Tipasie, w: Albert Camus, Zaślubiny. Lato, tłum. Maria Leśniewska, Wydawnictwo Literackie, Kraków.

Cohen Erik, 1988, Authenticity and Commoditization in Tourism, „Annals of Tourism Research”, t. 15, s. 371-386.

Dębicki Marcin, 2012, Z wędrówek po „opłotkach Europy”. Społeczno-kulturowe oblicze peryferii w twórczości Andrzeja Stasiuka, „Kultura i Społeczeństwo”, nr 1.

Gombrowicz Witold, 1989, Dziennik 1957-1961, Wydawnictwo Literackie, Kraków.

Gotchold Agnieszka 2013, Wstęp, w: Agnieszka Gotchold (red.), Interdyscyplinarność: podróż szlakiem kultur, Wydawnictwo Uniwersytetu Warszawskiego, Warszawa.

Heller Michał, 2014, Podróże z filozofia w tle, Znak, Kraków.

Janiszewska Aleksandra, 2012, Sport w przedwojennej Warszawie: wodniacy, cykliśsi, pitkarze, Fundacja Ośrodka Karta, Warszawa.

Klejnocki Jarosław, 2011, „Ponieważ nie chcę być pchta”, w: Jarosław Klejnocki, Andrzej S. Kowalczyk (red.), Buntownik, cyklista, Kosmopolak. O Andrzeju Bobkowskim i jego twórczości, Muzeum Literatury im. Adama Mickiewicza-Towarzystwo Więź, Warszawa.

Kowalczyk Andrzej S., 2010, Stowo o Bobkowskim, w: Andrzej Bobkowski, Aniela Mieczysławska, Listy 1951-1961, Wydawnictwo Więź, Warszawa.

Kozicka Dorota, 2003, Wędrowcy światów prawdziwych. Dwudziestowieczne relacje z podróży, Universitas, Kraków.

Lorenz Konrad, 2014, Rozmowy ze zwierzętami, tłum. Barbara Tarnas, Grupa Wydawnicza Foksal, Warszawa.

Łuba-Wróblewska Joanna, 2010, Cykliści. Sympatycy, pasjonaci, mistrzowie 1886-1939, Fundacja Ośrodka Karta-Dom Spotkań z Historią, Warszawa.

Michalak Sławomir, 2010, Poznański epizod w życiu Konrada Lorenza, „Neuroskop”, nr 12, s. 118-121.

Platon, 1991, Państwo, t. 1, tłum. Władysław Witwicki, Wydawnictwo AKME, Warszawa.

Plucińska-Smorawska Katarzyna, 2005, Między historia a literaturą. O Szkicach piórkiem Andrzeja Bobkowskiego, Wydawnictwo Neriton, Warszawa.

Podolska Joanna, 1998, Pottuczona mozaika. Andrzeja Bobkowskiego myśli o epoce, Wydawnictwo UMCS, Lublin.

Sahaj Tomasz, 2008, Znane postaci, nieznani rowerzyści: W.I. Lenin, T. Węctawski, K. Nowak, w: Marek Kazimierczak (red.), W kreggu humanistycznej refleksji nad turystyką kulturowa, Wydawnictwo AWF, Poznań.

Sahaj Tomasz, 2011, Rytualnie odnawiane szczęście: podróże filozoficzno-sportowe, „Folia Turistica”, nr 24, s. 119-136.

Sahaj Tomasz, 2015a, Andrzej Bobkowski: cyklista, „chuligan wolności”, wagabunda. Filozoficzny memoriał w 100-lecie urodzin, w: Maria Zowisło, Jerzy Kosiewicz (red.), Sport $i$ turystyka $w$ zwierciadle wartości społecznych, Wydawnictwo AWF, Kraków.

Sahaj Tomasz, 2015b, Andrzej Bobkowski - turysta kulturowy czy sportowy? Studium przypadku, w: Marek Kazimierczak (red.), Turystyka sportowa. Społeczno-kulturowy potencjat i perspektywy rozwoju, Wydawnictwo AWF, Poznań.

Sorokin Pitirim A., 2009, Ruchliwość społeczna, tłum. Jerzyna Słomczyńska, Wydawnictwo IFiS PAN, Warszawa.

Stasiuk Andrzej, 2000, Tekturowy samolot, Wydawnictwo Czarne, Wołowiec.

Urbanowski Maciej, 2013, Szczęście pod wulkanem. O Andrzeju Bobkowskim, Wydawnictwo LTW, Łomianki.

Węcławski Tomasz, 1997, Teolog i rower, w: Romana Brzezińska i in. (red.), Poznaniacy, portretów kopa $i$ trochę, Wydawnictwo W drodze, Poznań.

Wieczorkiewicz Anna, 2012, Apetyt turysty. O doświadczaniu świata w podróży, Universitas, Kraków. 
Wiza Agata, 2013, Uczenie się z podróży w narracjach turystów indywidualnych (backpackersów), Wydawnictwo AWF, Poznań.

\section{ANDRZEJ BOBKOWSKI'S TRAVELS AND CYCLE TOURS}

\section{Summary}

The purpose of this article is to present and analyze selected travel accounts by the Polish emigrant Andrzej Bobkowski (1913-1961). In France, in spite of the ongoing war and then the German occupation, he undertook a number of cycling and sports-tourist expeditions; his phenomenal descriptions of these journeys have become part of the Polish literary canon. Bobkowski called his travels 'bicycle tours' and for him they were a form of expression inextricably connected with authentic existence and personal freedom in a world of totalitarianisms. The author employs comparative and the qualitative methods (content analysis) of scholarship.

\section{Key words / słowa kluczowe}

Andrzej Bobkowski; literature /literatura; journey / podróż; biking / rower; tourism / turystyka 